\title{
The biological activities of vitamin A acetate and vitamin A palmitate: experiments with chickens
}

\author{
L. Bolhuis and $\mathrm{K}$. Kortenoeven
}

NV Philips-Duphar Research Laboratories, Weesp, the Netherlands

Received 12 December 1968

\section{Summary}

In four chicken experiments (1-4) the utilization of vitamin A from either the acetate or the palmitate ester in aqueous solution was compared by using the liver storage test. In these experiments the vitamin A levels in the livers, three days after administering a single oral massive dose of 11000-12000 I.U. vitamin A, tended to be higher in the chickens which had been dosed with the aceiate ester. In two of the trials the difference in utilization proved to be significant statistically $(\mathbf{P}<0.05)$.

In Experiment 3 the chickens were kept on a vitamin $A$ free ration for a period of 8 weeks after having received the oral massive dose. During this period higher vitamin A levels were maintained in the livers of the chickens which had received the acetate ester.

In Experiment 4 chickens having been dosed at 7 days of age were kept until 12 weeks of age on a ration fortified with 7.5 I.U. vitamin A (as acetate) per g. A higher vitamin $A$ level in the livers was maintained during the 12 week period by the chickens which received the acetate ester dose, although the difference did not reach significance. Undosed chickens, kept as a parallel group in this experiment, showed vitamin A liver levels which were so much lower than those of the dosed groups as was accounted for by the amount of vitamin A stored from the massive dose. This difference was maintained during the complete trial period.

In another two experiments dry, stabilized vitamin A preparations containing either the acetate or the palmitate ester were mixed through the feed. Vitamin A levels in the livers after 8 weeks in both experiments tended to be higher in the chickens having received the acetate ester, the combined results showing the difference to be significant $(\mathrm{P}<0.05)$.

\section{Introduction}

In some recently published journals and pamphlets it has been stated that the vitamin A palmitate ester is superior over the vitamin A acetate ester, not only with regard to stability but also to efficacy. No proof of this, however, could be found in the scientific periodicals. Olsen c.s. (29) mixed gelatin coated vitamin A acetate and vitamin A palmitate (using 200,600 or 1200 I.U. vitamin $A / 1 b$ ) in a chicken ration and did not find any difference in liver storage of the two esters.

This result was also obtained by Braekkan (7) using 150000 I.U. vitamin A per $\mathrm{kg}$ feed in a 7-day chicken experiment; however, when 10000 I.U. of vitamin A per 
chicken was administered orally by the dropper method, a statistically significant better liver storage was obtained with the acetate than with the palmitate ester. In two later experiments with chickens (10) no difference in vitamin A availability of the same two esters could be found after oral administration of about 3800 I.U. vitamin A per chicken. In two experiments with rats, in which 1000 and 2000 I.U. per animal were administered once, vitamin $A$ acetate showed a significantly better liver storage than vitamin A palmitate in one experiment, while no significant difference was found in the second experiment.

In order to obtain first hand information on this subject a number of experiments was carried out during the period July 1963-September 1964 with chickens, using the liver storage test as the criterion for the utilization of the two esters.

\section{Literature}

From the numerous studies in which liver storage tests served as a criterion for the utilization of various vitamin A products (or carotenes) it has become clear that there are many factors which may influence the absorption or storage in the liver of vitamin $\mathrm{A}$. These factors can be associated with:

1. The vitamin A preparation
a. stability $(16,22,23,28)$
b. method of stabilization (11)
c. character of diluent $(6,11,13,14,23,24,39)$
d. quantity of diluent (14)
e. size of vitamin oil particles $(35,38)$
f. isomeric forms of vitamin $\mathrm{A}(6,12,37)$
g. kind of vitamin $\mathbf{A}$ ester $(7,10,21,25,29,39)$

2. The method of administration
a. dosing level $(1,8,11,16)$
b. single or divided dosage (8)
c. method of oral administration $(6,28)$
d. route of administration $(21,24)$

3. The animal
a. species of animal $(6,27,37)$
b. breed/strain (33)
c. age $(4,5,8,15,33)$
d. $\operatorname{sex}(5,6,18,27,31)$
e. state of health $(8,16,19,20,30)$
f. state of filling of alimentary tract $(6,23,26)$
g. variation between lots of animals (8)

4. The composition of the diet
a. fat content $(2,7,11,14,40)$
b. protein content $(2,3,18,34)$
c. feed ingredients $(17,32)$
d. feed additives $(22,36)$

5. The interval between dosing and sampling (9)

Hence in the underlying studies the experimental procedures were standardized as much as possible. 


\section{Experimental part}

In 4 experiments a single oral massive dose of an aqueous solution of vitamin $\mathrm{A}$ acetate or palmitate was administered to broiler type chickens ( $11000-12000$ I.U. per bird). In Experiments 1 and 2 only the initial storage of vitamin $A$ in liver 3 days after dosing was determined. In Experiments 3 and 4 storage determinations in liver were carried out at various intervals after dosing, the difference between these two tests being that in Experiment 3 the basal ration did not contain vitamin $A$ while in Experiment 4 the basal ration was fortified with 7500 I.U. vitamin A per $\mathrm{kg}$ feed. In two other experiments (5 and 6) the utilization of dry stabilised vitamin $A$ acetate or palmitate preparations mixed through the feed was compared by determining the vitamin A levels in liver at the end of an 8 week experimental period.

Table 1 Composition of the basal ration, the mineral mixture and the vitamin antibiotic mixture

\begin{tabular}{|c|c|c|c|c|c|c|}
\hline $\begin{array}{l}\text { Composition of the } \\
\text { basal ration (\%) }\end{array}$ & & $\begin{array}{l}\text { Composition of the } \\
\text { mineral mixture }(\%)\end{array}$ & & $\begin{array}{l}\text { Composition of th } \\
\text { vitamin antibiotic } \\
\text { mixture (per } \mathrm{kg}\end{array}$ & ation) & \\
\hline Animal fat (stabilized) & 3.5 & Calcium carbonate & 45.35 & Vitamin $\mathbf{D}_{3}$ & 1500 & I.U. \\
\hline White maize meal & 39.5 & Dicalcium phosphate & 40.00 & Vitamin $\mathrm{E}$ & 5 & I.U. \\
\hline Milocorn & 15.5 & Iodized salt & 12.50 & Vitamin $\mathrm{K}_{3}$ & 1. & $5 \mathrm{mg}$ \\
\hline Sesame oil meal & 9 & Copper sulphate & 0.15 & Vitamin $\mathbf{B}_{\mathbf{2}}$ & 3 & $\mathrm{mg}$ \\
\hline Soyabean oil meal & 23 & Manganese sulphate & 1.20 & Pantothenic acid & 4 & $\mathrm{mg}$ \\
\hline Fishmeal (Peru) & 7 & Zinc sulphate & 0.30 & Nicotinic acid & 15 & $\mathrm{mg}$ \\
\hline Mineral mixture & 2 & Potassium iodide & & Vitamin $\mathbf{B}_{6}$ & 0. & $3 \mathrm{mg}$ \\
\hline $\begin{array}{l}\text { Vitamin antibiotic } \\
\text { mixture }\end{array}$ & 0.75 & preparate & 0.50 & $\begin{array}{l}\text { Vitamin } \mathbf{B}_{12} \\
\text { Choline chloride }\end{array}$ & $\begin{array}{r}8 \\
150\end{array}$ & $\mu \mathrm{g}$ \\
\hline Zoamix-25 & 0.05 & & & $\begin{array}{l}\text { Vitamin C } \\
\text { Procaine penicillin }\end{array}$ & $\begin{array}{r}10 \\
6\end{array}$ & $\mathrm{mg}$ \\
\hline
\end{tabular}

\section{Basal ration and vitamin $A$ preparations}

Table 1 gives the basal ration used in all six experiments. The mineral mixture and the vitamin antibiotic mixture used in the basal ration are specified in this table too. The aqueous solutions used contained per gramme approximately 10000 I.U. vitamin $A+5000$ I.U. vitamin $D_{3}$. The mineral stable vitamin $A$ preparations used in Experiments 4, 5 and 6 had a potency of 325000 I.U. of vitamin A per gramme. ${ }^{1}$

\section{Method of dosing}

The aqueous solutions were administered to the chickens by $1 \mathrm{ml}$ syringes, the contents of which had been measured carefully; each chicken received the full content of the syringe used.

\section{Analytical procedure}

The vitamin A content in the livers was determined colorimetrically after grinding the livers, saponification and extraction. The vitamin $A$ extract was treated with the reagent of Carr and Price.

1 The preparations used were 'Dohyfral Extra' A-325, dry gelatin sugar coated mineral stable products manufactured by Philips-Duphar, Weesp, Holland. 


\section{Experiment 1}

This experiment was started with 250 day-old, unsexed North Holland Blue (NHBl) chickens on litter in an electrically heated house. After 7 days 200 chickens were taken off the feed simultaneously for being dosed with one of the two vitamin $A$ preparations, the remainder of the chickens being kept for control determination. Dosing took place in lots of 25 chickens in the order acetate-palmitate-palmitateacetate-acetate- and so on. Soon after dosing each lot was returned to the feed. The chickens were dosed with either 11960 I.U. vitamin A as acetate or 11510 I.U. vitamin $A$ as palmitate and were sacrificed 68 hours after being dosed. The livers were pooled in lots of 10 for vitamin A determination. The results (after correction for vitamin $A$ level of the undosed chickens) are given in Table 2, the data in which show a tendency to a higher storage of vitamin $A$ in the livers from the acetate ester; the difference is not significant.

Table 2 Vitamin $A$ in liver 68 hours after oral massive dose after correction for the vitamin $A$ level of the undosed chickens

\begin{tabular}{lccccc}
\hline & \multicolumn{2}{c}{ Acetate group } & & \multicolumn{2}{c}{ Palmitate group } \\
\cline { 2 - 3 } & $\begin{array}{c}\text { I.U. vitamin } \\
\text { A per liver }\end{array}$ & $\begin{array}{c}\text { Percentage of } \\
\text { dose stored }\end{array}$ & & $\begin{array}{c}\text { I.U. vitamin } \\
\text { A per liver }\end{array}$ & $\begin{array}{c}\text { Percentage of } \\
\text { dose stored }\end{array}$ \\
Average & $3480 \pm 68$ & $29.2 \pm 0.56$ & & $3120 \pm 176$ & $27.1 \pm 1.54$ \\
\pm S.E. $* *$ & & & & &
\end{tabular}

** Standard error of the mean

\section{Experiment 2}

In order to obtain more conclusive information a second test was carried out. To exclude a possible sex influence, male and female chickens were equally divided over the two experimental groups. In this experiment 250 day-old, sexed NHBl chickens were used. After 10 days 200 chickens were dosed, the remainder of the chickens being kept for control determinations.

Dosing was carried out in lots of $10(5 s+5 q)$ in the order mentioned in Experiment 1 . The chickens were taken off the feed shortly before and returned to the feed immediately after being dosed with either 10880 I.U. vitamin A as the acetate ester or 11070 I.U. vitamin $A$ as the palmitate ester.

The chickens were sacrificed 72 hours after being dosed; the livers were pooled in lots of 5 , either as 3 livers of male chickens +2 livers of female chickens or re-

Table 3 Vitamin A in liver 72 hours after oral massive dose after correction for the vitamin $A$ level of the undosed chickens

\begin{tabular}{lccccc}
\hline & \multicolumn{2}{c}{ Acetate group } & & \multicolumn{2}{c}{ Palmitate group } \\
\cline { 2 - 3 } \cline { 5 - 6 } & $\begin{array}{c}\text { I.U. vitamin } \\
\text { A per liver }\end{array}$ & $\begin{array}{c}\text { Percentage of } \\
\text { dose stored }\end{array}$ & & $\begin{array}{c}\text { I.U. vitamin } \\
\text { A per liver }\end{array}$ & $\begin{array}{c}\text { Percentage of } \\
\text { dose stored }\end{array}$ \\
$\begin{array}{l}\text { Average } \\
\pm \text { S.E. }\end{array}$ & $4506 \pm 101$ & $41.4 \pm 0.93$ & & $4210 \pm 79$ & $38.0 \pm 0.72$ \\
\hline
\end{tabular}


versely. The results of this experiment (after correction for vitamin A level of the undosed chickens) are given in Table 3. They show that the vitamin A utilization from the aqueous vitamin $A$ acetate solution was significantly better $(P<0.05)$ than that from the aqueous vitamin A palmitate solution.

\section{Experiment 3}

As for practical purposes not only the initial resorption, but also the course of depletion after dosing is very important, a third experiment was carried out to investigate these two factors as well as a possible sex influence.

For this experiment 140 male +140 female NHBl chickens were used. When the chickens were 7 days old, 110 birds of each sex were dosed by syringe with either 11880 I.U. vitamin A as acetate or 11870 I.U. vitamin A as palmitate, the remainder of the chickens being kept for control determinations.

In addition to the dosing procedure as described in Experiment 2, the chickens in this experiment were divided over the two groups according to sex and weight.

At various intervals after dosing, 10 chickens of each sex per group were weighed and sacrificed; the livers of 9 chickens were pooled in lots of three, according to the weight of the birds, the chicken with the weight most deviating from the mean weight out of each lot of 10 being left out of consideration.

Of all the chickens that had been left undosed, more than half had died before reaching 4 weeks of age; the remaining undosed chickens were by that time in such poor condition that they were removed from the experiment.

The results of this experiment (after correction for the initial vitamin A level (20 I.U.) of the chickens) are summarized in Table 4. The data of Table 4 show that also in this experiment the initial storage in the livers (at 3 days) from the acetate ester was significantly higher than from the palmitate ester $(\mathrm{P}<0.05)$.

Expressed as percentage of the dose given, the resorption at 3 days was:

$\begin{array}{lcc} & \text { Acetate group } & \text { Palmitate group } \\ \text { male chickens } & 38.9 \pm 2.98 & 28.1 \pm 2.52 \\ \text { female chickens } & 42.2 \pm 2.57 & 30.5 \pm 1.73 \\ \text { average } \pm \text { S.E. } & 40.5 \pm 1.91 & 29.3 \pm 1.47\end{array}$

Also during the course of the depletion period, the vitamin A levels in the livers of the acetate group remained higher than those in the livers of the palmitate group. However after the fourth week these differences were not statistically significant.

As to the influence of sex on the storage of vitamin $A$, the data show that on the

Table 4 Vitamin $A$ in liver ${ }^{1}$ at different intervals after oral massive dose after correction for the initial vitamin $A$ level (20 I.U.) of the chickens

\begin{tabular}{|c|c|c|c|c|c|c|}
\hline \multirow{2}{*}{$\begin{array}{l}\text { Time after } \\
\text { dosing }\end{array}$} & \multicolumn{3}{|c|}{ Acetate group } & \multicolumn{3}{|c|}{ Palmitate group } \\
\hline & males & females & average & males & females & average \\
\hline 3 days & 4620 & 5010 & 4815 & 3340 & 3620 & 3480 \\
\hline 4 weeks & 3050 & 3200 & 3125 & 2580 & 2780 & 2680 \\
\hline 6 weeks & 660 & 1530 & 1095 & 560 & 1370 & 965 \\
\hline 7 weeks & 420 & 1020 & 720 & 230 & 790 & 510 \\
\hline 8 weeks & 210 & 690 & 450 & 70 & 250 & 160 \\
\hline
\end{tabular}

1 Average (I.U.) of 9 livers 
whole the female chickens had higher vitamin A levels than the male chickens. The differences between the sexes were only significant $(P<0.05)$ for the acetate group at 6,7 and 8 weeks and for the palmitate group at 7 weeks, however.

No significant correlation between the live weight and the vitamin A level in the livers of the chickens could be found at any age. Concerning the live weights the difference between the two experimental groups was not significant as was to be expected.

\section{Experiment 4}

As under practical farming conditions the oral massive dose is mainly administered to animals which are kept on rations containing vitamin $\mathrm{A}$, a fourth experiment was carried out similar to Experiment 3, this time however using a basic ration fortified with 7.5 I.U. vitamin A (acetate) per gramme. This experiment was continued for 11 weeks after dosing. Also a greater number of undosed chickens was kept as a control group.

At 7 days of age, the chickens ( $\mathrm{NHBl)}$ were individually dosed by syringe with either 11580 I.U. vitamin A as the acetate ester or 11630 I.U. vitamin A as the palmitate ester. The results of this experiment (after correction for the initial vitamin A level, 100 I.U., of the chickens) are given in Table 5 and 6 . The data of Table 5 again show a tendency for a better initial utilization of vitamin A from the oral massive dose of the acetate ester than from the palmitate ester. Also during the course of the experiment the vitamin A level remained higher in the acetate group. The differences turned out to be not significant statistically, however.

From Table 6 can be seen that during the course of the experiment the dosed chickens maintained a constantly higher level of vitamin A than the undosed chickens, the absolute difference, curiously enough, being slightly higher than the initial amount stored from the dose. This is quite contrary to expectations as a luxury use of the vitamin A stored from the dose could be expected.

An influence of sex on the amount of vitamin A stored from the oral massive dose, initially and during the course of the experiment, could not be demonstrated.

Significant differences in growth were not observed in this experiment, neither between the acetate and palmitate dosed chickens, nor between the dosed and undosed chickens, which is according to expectations.

When the results of the four experiments are summarized in respect of the initial

Table 5 Vitamin $A$ in liver ${ }^{1}$ at different intervals after oral massive dose after correction for the initial vitamin A level (100 I.U.) of the chickens

\begin{tabular}{|c|c|c|c|c|c|c|}
\hline \multirow{2}{*}{$\begin{array}{l}\text { Time after } \\
\text { dosing }\end{array}$} & \multicolumn{3}{|c|}{ Acetate group } & \multicolumn{3}{|c|}{ Palmitate group } \\
\hline & males & females & average & males & females & average \\
\hline 3 days & $3540 ?$ & 4380 & 3960 & 3900 & 3300 & 3600 \\
\hline 4 weeks & 5660 & 6090 & 5875 & 4910 & 6650 & 5780 \\
\hline 6 weeks & 7660 & 9200 & 8430 & 7840 & 8260 & 8050 \\
\hline 8 weeks & 10040 & 10800 & 10420 & 9840 & 9930 & 9885 \\
\hline 9 weeks & 13170 & 11230 & 12200 & 12820 & 11380 & 12100 \\
\hline 11 weeks & 15980 & 15310 & 15645 & 13670 & 14520 & 14090 \\
\hline
\end{tabular}

\footnotetext{
1 Average (I.U.) of 9 livers

2 One of the three analyses showed a very low figure (1930 I.U. vitamin A per liver)
} 
Table 6 Vitamin $\boldsymbol{A}$ in liver of chickens on basic ration only, and difference dosedundosed chickens after correction for the initial vitamin $A$ level (I00 I.U.) of the chickens

\begin{tabular}{rrrrr}
$\begin{array}{l}\text { Age of } \\
\text { chickens }\end{array}$ & Males & Females & Average & $\begin{array}{c}\text { Difference dosed } \\
\text { and undosed chickens }\end{array}$ \\
7 weeks & 4270 & 3670 & 3970 & 4270 \\
9 weeks & 5630 & 6520 & 6075 & 4080 \\
10 weeks & 8270 & 7270 & 7895 & 4260 \\
12 weeks & 11530 & 9130 & 10330 & 4540 \\
\hline
\end{tabular}

t Average of acetate group and palmitate group: see Table 5

storage of vitamin $\mathrm{A}$ in the livers from the oral massive dose of the two vitamin $\mathrm{A}$ esters, statistical treatment of the data shows the difference in storage in the livers to be not significant.

\section{Experiment 5}

In this experiment the utilization of vitamin A from a stabilized preparation of vitamin $A$ acetate and of vitamin A palmitate, administered through the feed (7.5 I.U./g), was measured by determining the vitamin $A$ level in the livers of the chickens after 8 weeks on test.

Both preparations were fed to two groups of 100 fast growing male broiler chickens (Cobb) kept under equal housing conditions. At 8 weeks of age from each treatment 36 chickens of mutual comparable weight, divided over 3 weight ranges, were sacrificed and their livers pooled in lots of 3 for vitamin $A$ determinations. The results of this test are given in Table 7. The figures of this table show that in all subgroups the utilization of vitamin $A$ from the acetate ester tended to be better than from the palmitate ester. However, the overall difference between the treatments was not significant statistically. No significant differences between the two vitamin ester groups were observed with respect to growth or feed conversion.

Table 7 Vitamin A in liver and liver weight of chickens given 7.5 I.U. vitamin $A$ per $g$ feed for 8 weeks ${ }^{1}$

\begin{tabular}{|c|c|c|c|c|}
\hline \multirow{2}{*}{$\begin{array}{l}\text { Weight range } \\
\text { of chickens } \\
(\mathrm{g})\end{array}$} & \multicolumn{2}{|c|}{ Acetate group } & \multicolumn{2}{|c|}{ Palmitate group } \\
\hline & $\begin{array}{c}\text { liver weight } \\
(g)\end{array}$ & $\begin{array}{l}\text { I.U. vitamin } \\
\text { A per liver }\end{array}$ & $\begin{array}{c}\text { liver weight } \\
(g)\end{array}$ & $\begin{array}{l}\text { I.U. vitamin } \\
\boldsymbol{A} \text { per liver }\end{array}$ \\
\hline $1510-1565$ & $30.7 \pm 0.76$ & $8840 \pm 657$ & $29.8 \pm 0.91$ & $8090 \pm 310$ \\
\hline $1650-1685$ & $34.0 \pm 1.15$ & $9940 \pm 365$ & $31.7 \pm 0.65$ & $9620 \pm 505$ \\
\hline $1825-1865$ & $36.2 \pm 1.10$ & $10840 \pm 766$ & $34.5 \pm 1.20$ & $9940 \pm 619$ \\
\hline
\end{tabular}

$1 \quad$ Average \pm S.E. of $4 \times 3$ livers

As in this trial a significant overall difference $(P<0.05)$ in liver weight was found between the two groups, for which no explanation could be given, it was decided to repeat this experiment. 


\section{Experiment 6}

In this trial 50 male broiler chickens were used per vitamin ester group and kept in a battery brooder. The basic ration contained 8.25 I.U. vitamin A per g, either as the acetate or as the palmitate ester.

At 8 weeks of age 36 chickens from each group were chosen at random, sacrificed and their livers pooled in lots of three according to increasing live weight of the chickens. The results of this trial are given in Table 8 . The figures in this table again show a higher utilization of vitamin A from the acetate ester than from the palmitate ester. Statistical treatment of the data, however, showed that the difference is not significant. Contrary to Experiment 5 no sign of a tendency to a difference in liver weight between the two groups could be found in this experiment.

Again no significant difference in growth and in feed conversion between the two vitamin ester groups was found.

A statistical treatment of the combined results of the last two experiments showed the higher vitamin A storage in the livers from the acetate ester to be significant $(\mathrm{P}<0.05)$.

Table 8 Vitamin $A$ in liver, live weight and liver weight of male chickens given 8.25 I.U. vitamin $A$ per $g$ feed for 8 weeks

\begin{tabular}{|c|c|c|c|c|c|c|}
\hline & \multicolumn{3}{|c|}{ Acetate group } & \multicolumn{3}{|c|}{ Palmitate group } \\
\hline & $\begin{array}{c}\text { live weight } \\
\text { of chickens } \\
(\mathrm{g})\end{array}$ & $\begin{array}{c}\text { liver weight } \\
(g)\end{array}$ & $\begin{array}{c}\text { vitamin } A \\
\text { level per } \\
\text { liver (I.U.) }\end{array}$ & $\begin{array}{l}\text { live weight } \\
\text { of chickens } \\
\text { (g) }\end{array}$ & $\begin{array}{c}\text { liver weight } \\
(g)\end{array}$ & $\begin{array}{l}\text { vitamin } A \\
\text { level per } \\
\text { liver (I.U.) }\end{array}$ \\
\hline $\begin{array}{l}\text { Average } \\
\pm \text { S.E. }\end{array}$ & $1575 \pm 53$ & $33.6 \pm 1.06$ & $11833 \pm 596$ & $1628 \pm 52$ & $33.8 \pm 1.22$ & $11114 \pm 247$ \\
\hline
\end{tabular}

\section{Discussion}

The results of the chicken experiments described confirm the results obtained by Braekkan $(7,10)$, showing that the utilization of vitamin A from the acetate ester is equal to or better than that from the palmitate ester. In two of the four oral massive dose experiments the vitamin A storage in livers from the acetate ester, 3 days after dosing, was significantly better $(\mathrm{P}<0.05)$, while in the other two experiments the observed difference was not significant. The overall difference also turned out to be not significant.

In the Experiments 5 and 6, in which stabilized dry vitamin A preparations were mixed through the feed, the storage in livers after 8 weeks also tended to be better from the acetate ester, the combined results showing the difference to be significant $(\mathrm{P}<0.05)$.

No explanation can be given for the great variation in resorption between the various experiments, as standard procedures were followed as much as possible. The state of development of the chickens may have played a role $(8,15)$.

The results of Experiment 3 indicate that an oral massive dose supplying about 12000 I.U. vitamin A will provide sufficient vitamin A for approximately 8 weeks to chickens kept on a vitamin $A$ free ration. Vitamin $A$ stores in liver in this experi- 
ment decreased slowly during the first 4 weeks after dosing, at a fast rate during the 5 th and 6th week, followed again by a slow decrease during the last two weeks of the experiment. The fall in vitamin A liver store during the first 4 weeks was higher in the chickens having stored more vitamin A from the oral dose. This is in fair agreement with the results obtained by Braekkan (9) in chickens, but different from the results obtained in rats by Kring et al. (21) who found that the rate at which the vitamin A depot disappears from the liver increases with decreasing vitamin A content. De Man et al. (24) found no loss of vitamin A in the livers of rats 4 weeks after dosing 9000 I.U. vitamin $A$ from an oily, or 11000 I.U. vitamin A from an aqueous palmitate solution.

The results of Experiment 4 are very interesting as they show that it is possible to provide chickens kept on a normal vitaminized ration, at a very early age ( 7 days), with an extra store of vitamin $A$ in the liver which is maintained for a long period.

The vitamin A levels in the liver obtained in Experiments 5 and 6 are well in line with the results obtained by Panda et al. (30) and Krieg et al. (20) but are far above the levels obtained by Harms et al. (17).

No statistically significant influence of sex on the vitamin A resorption could be found, which is in accordance with literature.

\section{Acknowledgments}

We gratefully acknowledge the advice and the encouragement received from $\mathrm{Dr}$ Th. J. de Man.

\section{References}

Ames, S. R. \& Harris, P. L., 1956. Analyt. Chem. $28: 874$.

Ascarelli, I. \& Senger, M. J., 1962. J. Sci. Fd Agric. 13: 332.

3 Baumann, C. A., Forster, E. G. \& Moore, P. R., 1942. J. biol. Chem. 142: 597.

4 Bolin, D. W., Lampan, C. E. \& Berg, L. R., 1943. Poult. Sci. $22: 348$.

Booth, V. H., 1952. J. Nutr. $48: 13$.

6 Braekkan, O. R., Lambertsen, G., Enjaa, L. R. \& Utne, F., 1960. Int. Z. VitamForsch. $30: 363$.

7 Braekkan, O. R., 1962. Int. Z. VitamForsch. $32: 284$.

8 Braekkan, O. R., 1962. Int. Z. VitamForsch. 32: 369.

9 Braekkan, O. R., 1963. Int. Z. VitamForsch. 33: 154.

10 Braekkan, O. R., 1963. Int. Z. VitamForsch. 33: 234.

11 Brüggemann, J. \& Tiews, J., 1956. Z. Tierern. Futtermittelk. 11: 20.

12 Brüggemann, J. \& Tiews, J., 1959. Naturwissenschaften $46: 429$.

13 Esh, G. C. \& Bhattacharya, S., 1954. Nutr. Abstr. Rev. 24: 1712.

14 Foy, J. R. \& Morgareidge, K., 1948. Analyt. Chem. 20: 304.

15 Grimbergen, A. H. M. \& Cornelissen, J. P., 1960. Landbouwk. Tijdschr. 72 : 88 .

16 Harms, R. H., Reid, B. L. \& Couch, J. R., 1955. Poult. Sci. 34: 1125.

17 Harms, R. H., Camp, A. A., Reid, B. L., Grant, E. L., Greech, B. G. \& Couch, J. R., 1956. Poult. Sci. $35: 285$.

18 Jagannathan, S. N. \& Patwardhan, V. N., 1960. Indian J. med. Res. $48: 775$.

19 Klimes, B. \& Gazo, M., 1962. Arch. Geflügelk. 26: 165.

20 Krieg, R. \& Loliger, H. Ch., 1963. Arch. Geflügelk. 17: 483.

21 Kring, P. L., Lassen, J. B. \& Lund, A., 1964. Int. Z. VitamForsch. 34 : 218.

22 Luther, G. G., Goett, E. J. \& Cragwall, G. O., 1952. Int. Z. VitamForsch. 23 : 362.

23 Man, Th. J. de, Ham, E. J. ten, Roborgh, J. R. \& Zwiep, N., 1958. Neth. J. agric. Sci. 6: 237.

24 Man, Th. J. de, Roborgh, J. R. \& Ham, E. J. ten, 1958. Tijdschr. Diergeneesk. 83: 380.

25 March, B. E., English, E. \& Biely, J., 1952. Archs Biochem. Biophys. 36: 259. 
26 Mendeloff, A. T., 1953. J. Lab. clin. Med. $42: 924$.

27 Moore, T., 1957. Vitamin A.

28 Nyveld, W. J., 1957. Bedrijfspluimveehouder $35: 8$.

29 Olsen, E. M., Harvey, J. D., Hill, D. C. \& Branion, H. D., 1959. Poult. Sci. 38 : 929.

30 Panda, B., Combs, G. F. \& DeVolt, H. M., 1964. Poult. Sci. 43 : 154.

31 Parrish, D. B., Zimmerman, R. A., Sanford, P. E. \& Hung, E., 1963. J. Nutr. 79.

32 Recheigl, M., Berger, S., Loosly, J. K. \& Williams, H. H., 1962. J. Nutr. $76: 435$.

33 Shellenberger, T. E., Parrish, D. B. \& Sanford, P. E., 1964. J. Nutr. 82 : 99.

34 Stoewsand, G. S. \& Scott, M. L., 1960. Poult. Sci. 39: 1297.

35 Tagwerker, F. J., 1961. Wiener tierärztl. Monatschr. 48: 661.

36 Tiews, J., 1957. Landwirtsch. Forschung 9, Sonderheft, p. 148.

37 Tiews, J., 1961. Zentbl. VetMed. 8: 865.

38 Tiews, J. \& Kring, P. L., 1962. Int. Z. VitamForsch. 32: 258.

39 Week, E. F. \& Sevigne, F. J., 1949. J. Nutr. 39: 233.

40 Week, E. F. \& Sevigne, F. J., 1950. J. Nutr. $42: 525$. 